\title{
Slaying THE LeVIATHAN: CRITICAL JURISPRUDENCE AND THE TREADY OF WAITANGI
}

\author{
K Upston-Hooper
}

This paper considers the perspectives of four contributors to the current discourse on the Treaty of Waitangi: Professor Jane Kelsey, Dr Paul McHugh, Professor F M Brookfield and Moana Jackson. The jurisprudential underpinnings of each authors arguments are examined. The paper focuses on the degree to which two new forms of jurisprudential thought, Critical Legal Studies and Critical Race Theory, have informed the Treaty discourse. The paper concludes that, although such critical jurisprudence has yet to permeate New Zealand jurisprudence in any meaningful way, Critical Race Theory could help transform post-settler legal thinking. This paper was awarded the Quentin-Baxter LLM prize in Public and International Law in 1997.

\section{INTRODUCTION}

It is trite to observe that the Treaty of Waitangi has undergone a renaissance in the past decade. A renaissance in which the nature of identity of all citizens is contested and the Treaty has been "constitutionalised". ${ }^{1}$ The scope, meaning and effect of this "constitutionalisation" has been the subject of an intense and heated discourse which has been occasionally unsightly and vicious. ${ }^{2}$ At the heart of this debate is a rejection of the traditional concept of sovereignty as unitary, indivisible and omnipotent. The envisaging of a post-colonial constitutional future is premised on the rejection of the constitutional past, the slaying of the Leviathan. ${ }^{3}$

* This is an edited version of a paper submitted as part of the VUW LLM programme.

1 Havemann "The 'Pakeha Constitutional Revolution?' Five Perspectives on Maori Rights and Pakeha Duties" (1993) 1 Waikato L R 53, 77.

2 McHugh "Legal Reasoning and the Treaty of Waitangi: Orthodox and Radical Approaches" in Oddie and Perrett (eds) Justice, Ethics and New Zealand Society (Oxford University Press, Auckland, 1992) 91, 104.

3 Hobbes Leviathan, or Matter, Forme \& Power of a Common-wealth Ecclesiasticall and Civill (1651) reprinted, Penguin Books, London, 1961). Hobbes uses Leviathan, the great sea monster from the 


\section{TREATY DISCOURSE AND JURISPRUDENCE}

\section{A Kelsey}

Professor Jane Kelsey is one of New Zealand's leading contributors ${ }^{4}$ to the debate on the role and function of the Treaty of Waitangi in our contemporary society.

The thesis of Kelsey's work is that the New Zealand state has since 1840 faced a fundamental contradiction between colonial capitalism and the "rights of the tangata whenua to their own political and economic sovereignty". 5 Kelsey argues that this fundamental contradiction was finally exposed by the conflict between the fourth Labour Government's Treaty policy and its Rogernomics ideals. She argues that, in response to this conflict, the dominant legal ideology, as represented by the courts and the Waitangi Tribunal, has temporarily resolved the "fundamental contradiction" in the interests of Pakeha capital. ${ }^{6}$ This process has accordingly suppressed and redefined Maori claims for tino rangatiratanga. Kelsey's thesis is founded on an instrumentalist view of the role of law in our society: ${ }^{7}$

Law is hegemonic, and subjects all who come within its scope to a reconstitution of their problems in terms which reflect the interests of the State.

At the heart of Kelsey's writing is an attempt to expose the invisibility of the law that leads people to view it as neutral and "somehow above politics and economics, more independent and more trustworthy".8 She deprecates the ideology of legal liberalism. This is not liberalism in the form of centre-left political beliefs, but the liberalism, or focus on the individual, primarily associated with the writings of John Locke. At the heart of legal liberalism is the view that individuals have rights over themselves and their property into which neither the government nor other individuals can intrude. In legal

Book of Job, as a metaphor for the unitary and indivisible power of the sovereign: "He has not his like among the strong things of the earth, that fearless nature, that heaven-confronting eye over all the pride of earth he reigns supreme": Old Testament, Book of Job, Ch 41.

4 Recognised by the award of a personal chair in law by Auckland University in 1997.

5 Kelsey A Question of Honour? Labour and the Treaty 1984-1989 (Allen \& Unwin, Wellington, 1989) 3.

6 Above n 5, 237.

7 Kelsey Rolling Back the State: Privatisation of Power in New Zealand/Aotearoa (Bridget Williams Books, Wellington, 1993) 192, quoting prominent neo-Marxist Maureen Cain "The General Practice of Lawyer and Client: Towards a Radical Conception" (1979) 3 IJSL 31,333. However, Kelsey notes at 191: "It would be wrong to suggest that law automatically reflects the prevailing economic and political interests. The relationship is much more fluid than that. Law constitutes, and is constituted by, the complex interaction of economic, political and social conditions".

8 Above $\mathrm{n}$ 7, 191. 
systems liberalism manifests itself in the form of the rule of law and the adversarial nature of legal process.

Kelsey's vitriolic attack on legal liberalism is focused on the line of judicial decisions that began with the 1987 New Zealand Maori Council case ${ }^{9}$ and also attacks the findings of the Waitangi Tribunal (following the Orakei Report ${ }^{10}$ ). Kelsey argues that the courts and the Waitangi Tribunal, in using the interpretive tool of the "principles of the Treaty", have essentially rewritten the Treaty so as to deny tino rangatiratanga (as guaranteed by Article Two of the Maori version of the Treaty) and have consequently "legitimated and entrenched Pakeha political and economic power". ${ }^{11}$

Kelsey conceptualises this redefinition of the Treaty as a Gramscian "passive revolution": 12

The inclusion of new social groups under the hegemony of the political order without any

expansion of real political control by the mass of the population over politics.

Kelsey argues that by this process of "passive revolution" Maori have been encouraged to see the State as the neutral arbiter of the competing interests of its citizens. The concept of "passive revolution" is utilised by Kelsey to dismiss concessions and promises of change made by the State as being merely part of a strategy of divide and rule until the challenge of tino rangatiratanga to the State's authority is diffused.

In addition to challenging the role of the judiciary and the Waitangi Tribunal, Kelsey also attacks lawyers and academics for their role in the "passive revolution" which has resulted in the limiting and redefining of tino rangatiratanga: ${ }^{13}$

Lawyers who are a party to the judicialisation of the Treaty act as the organic intellectuals of

both capital and Pakeha hegemony whichever "side" they are on.

She argues that almost all academics speak from a position of not only cultural ignorance but also arrogance. ${ }^{14}$ Kelsey acknowledges that the challenge for her as a white

9 New Zealand Maori Council v Attorney General [1987] 1 NZLR 641.

10 Report of the Waitangi Tribunal on the Orakei Claim Wai-9 (1987).

11 Kelsey "Rogernomics and the Treaty: An Irresolvable Contradiction" (1989) 7 Law in Context 66, 85.

12 Above n 7, 234 quoting Sassoon Gramsci's Politics (2 ed, Hutchinson, London 1987) 210.

13 Above $n$ 11, 69.

14 Above n 5, 263. 
academic is to make the critique of legal liberalism available to Maori. But Kelsey cautions that the path to liberation lies in the hands of the oppressed. ${ }^{15}$

Kelsey's conclusion is that the crisis the state faced in the early 1980s, as a result of Maori claims to tino rangatiratanga, has been temporarily resolved by the judiciary and the Waitangi Tribunal utilising the concept of "principles of the Treaty" to limit and redefine Maori claims. She argues that unless tino rangatiratanga is recognised, not as dependent or subordinate to the Pakeha state, but as part of a dual state with coexisting constitutional entities, then the Pakeha state risks organised and possibly violent resistance. ${ }^{16}$ We need only to look at Kanaki, Bougainville and Fiji to understand the long term consequences if the issue of self-determination is not grappled with soon. A country ruled by violence and repression is not desired by anyone. ${ }^{17}$

The jurisprudence of Kelsey has been described as belonging to, and being strongly influenced by, the Critical Legal Studies ("CLS") movement. ${ }^{18}$ The tenets and critique of CLS will be examined in depth in Part III of this paper. It is necessary, however, to briefly background CLS in order to provide perspective to Kelsey's critical jurisprudence and associated orthodox response.

The CLS movement is essentially a "left political location". ${ }^{19}$ It is a form of critical jurisprudence that utilises the tools of deconstruction to attempt to demystify legal liberalism, exposing the law as inherently indeterminate. CLS adherents hold that there is no interesting difference between legal discourse and ordinary moral and political discourse. $^{20}$

The origins of CLS are eclectic, and to some extent amorphous. It is indebted to the deconstruction tools of legal realism and the critical concepts derived from the continental philosophy of Antonio Gramsci, the Frankfurt School, Jean-Paul Sartre and Jurgen Habermas. This group forms the nucleus of critical Marxist jurisprudence.

15 Above $\mathrm{n} 11,71$.

16 Above n 7, 363: "The danger to the state and capital lies in organised - not necessarily violent Maori resistance" [emphasis added].

17 Kelsey "The Treaty of Waitangi and Maori Independence - Future Directions" (1990) 9th Commonwealth Law Conference papers, 249, at 254.

18 Brookfield "Maori Rights and Two Radical Writers: Review and Response" [1990] NZLJ 406, 407 and McHugh "Legal Reasoning and the Treaty of Waitangi: Orthodox and Radical Approaches" in Oddie and Perrett (ed) Justice, Ethics and New Zealand Society (Oxford University Press, Auckland, 1992) $91,99$.

19 Tushnet "Critical Legal Studies: A Political History" (1991) 100 Yale L J 1515, 1515.

20 Above n 19, 1524. 
Critical Marxism is distinguishable from its scientific Marxist antecedent by its rejection of the inevitability of the collapse of capitalism and its abandonment of economic determinism. ${ }^{21}$ The central tenet of critical Marxism is a focus on ideas as a source of social change. There is a focus on consciousness and culture; on how people come to give meaning to their social world; on how they come to absorb ideologies that interpret the world in the interests of the dominant groups. ${ }^{22}$ Critical Marxism seeks to empower the oppressed, to alter their consciousness so as to enable them to free themselves from the unjust status quo.

The primary contribution of critical Marxism to CLS jurisprudence is the concepts of ideology and hegemony: ${ }^{23}$

Ideology and hegemony are concepts used to explain how such groups manage to maintain a
superior position over a larger mass of people without the constant use of force or the threat of
force. An ideology is a way of understanding and interpreting the world that reflects the
interests and biases of a particular group, but which presents itself as neutral and unbiased.
The dominant group's ideology will explain and justify that group's privileged position by
means of notions such as natural order ordained by a deity, or flowing from the nature of man,
or produced by the invisible hand of the marketplace. Hegemony is achieved when members
of subordinate groups internalise to a significant extent the ideology of the dominant group
and so accept the legitimacy of the status quo. Many important features of society then come to
seem fixed or unalterable. Alternatives to them are difficult even to conceive.

The jurisprudence of Kelsey relies heavily on the concepts of ideology and hegemony to explain the "passive revolution" of how apparent the judicial victories of Maori in the last decade actually served to legitimate the interests of the state and the privileged few Pakeha who benefit from capitalism.

However, to categorise Kelsey as a CLS scholar is overly simplistic and collapses all critical jurisprudence into a convenient (and pejorative) label that becomes so wide as to lack meaning. The jurisprudence of Kelsey is that of critical Marxism, as evidenced by her intellectual reliance on Antonio Gramsci and her constant polemic directed against capitalism. The fact that CLS scholars have eclectically borrowed the critical Marxist concepts of ideology and hegemony should not result in a categorisation of Kelsey as a CLS scholar. Any such categorisation would be premised on the false assumption that the "Left" is a homogenous and unified intellectual location.

21 For a fuller discussion of the development of Marxist jurisprudence see Robertson "Critical Legal Studies and Socialism" (1991) 14 NZULR 355.

22 Above n 21, 363.

23 Above n 21, 362. 
In fact, the vast array of Kelsey's writing contains only one reference to a CLS scholar. ${ }^{24}$ Futhermore, Kelsey's analysis of the courts and the Waitangi Tribunal is essentially orthodox academic doctrinal analysis. Unlike CLS scholars, such as Kennedy, ${ }^{25}$ Kelman $^{26}$ and Klare, ${ }^{27}$ Kelsey does not seek to penetrate the surface of social reality and expose the effect of law on the actual workings of society. Her work, in contrast to that of CLS scholars, is bereft of an analysis of the effect of the Treaty decisions on the "Grace Hekes"28 of New Zealand. Despite her self-proclaimed challenge of making the critique of legal liberalism accessible to Maori, Kelsey makes no attempt to utilise a creative narrative methodology in order to aid in the communication of her thesis.

In addition, as discussed in Part III, CLS contains a damning critique of the legal liberal conception of rights. This critique of the "myth of rights" is absent from Kelsey's thesis, although she does acknowledge that: ${ }^{29}$

[The] Western definition of indigenous rights merely maintains the authority and power of those who do the defining. It in effect says that tangata whenua possess those individual rights which recognise that they are born free and equal in dignity, but they do not possess the collective right to self-determination which recognised that they are free and equal in sovereign power.

However, Kelsey is not attacking rights as being "passivising illusions" 30 but merely arguing for collective rather than individual rights. Kelsey's rights stance further distances her jurisprudence from CLS.

In summary, Kelsey's work attempts to prove that legal liberalism is structurally incapable of providing justice to Maori in terms of tino rangatiratanga. ${ }^{31}$ What tino rangatiratanga actually means in the late twentieth century is largely ignored by Kelsey.

24 Klare "Judicial Deradicalisation of the Wagner Act and the Origins of Modern Legal Consciousness 1937-1941" in Bierne and Quinney (eds) Marxism and the Law (Wiley, Canada, 1982).

25 Kennedy "Form and Substance in Private Law Adjudication" (1976) 89 Harvard L Rev 1685.

26 Kelman "Interpretive Construction in the Substantive Criminal Law (1981) 33 Stanford L Rev 591.

27 Klare "The Post-War Paradigm in American Labor Law" (1981) 90 Yale L J 1509.

28 The tragic lead character in Duff Once Were Warriors (Tandem Press, Auckland, 1990).

29 Above n 17, 254.

30 Gabel and Kennedy "Roll over Beethoven" (1984) 36 Stanford L Rev 1, 33.

31 Above n 11, 70. 
She notes it is absolute control and authority over all precious tangible and intangible things ${ }^{32}$ but does not convert this abstraction into a politically recognisable reality.

It is submitted that the jurisprudence of Kelsey's "passive revolution" is derived directly from critical Marxism rather than second hand from CLS. Although there is an overlap due to the eclectic borrowing of CLS from critical Marxism, the orthodox categorisation of Kelsey as a CLS scholar ignores the details of her writing and collapses too many concepts under the convenient tag of CLS.

\section{B McHugh}

The other primary contributor to New Zealand's Treaty discourse is Dr Paul McHugh. McHugh has described himself as writing in the orthodox legal paradigm. ${ }^{33}$ This paradigm is defined by its adherence to the traditional concepts of the rule of law, the utility of the common law and unitary Parliamentary sovereignty. The writings of Professor Brookfield, which are considered in Part II D, also fall squarely within this paradigm.

Much of McHugh's early contribution to Treaty discourse focused on the rediscovery and application of aboriginal rights in the common law. ${ }^{34}$ This theme of his work has been gradually replaced by a focus on the indigenisation of constitutional discourse in New Zealand, and particularly the role of both law and history in this discourse. ${ }^{35}$ McHugh argues that the Treaty decisions have transformed New Zealand's constitutional discourse, forcing the Crown to listen to and negotiate with Maori. According to McHugh, this process of "horizontalisation" of the power relationship between Crown and Maori is part of a move towards the adoption of a form of constitution which recognises cultural diversity: ${ }^{36}$

A constitution should be seen as a form of activity, an intercultural dialogue in which the culturally diverse sovereign citizens of contemporary societies negotiate agreements on their forms of association over time in accordance with the three conventions of mutual recognition, consent and cultural continuity.

32 Above n 11, 71.

33 Above n 2, 91.

34 McHugh "The Legal Basis for Maori Claims Against the Crown" (1988) 18 VUWLR 1; McHugh "The Role of Law in Maori Claims" [1990] NZLJ 16.

35 McHugh "Constitutional Voices" (1996) 26 VUWLR 499.

36 Above n 35, 506: Quoting Tully Strange Multiplicity: Constitutionalism in an Age of Diversity (Cambridge, Cambridge University Press, 1995) 30. 
McHugh notes that, like the House of Lords in the Factortame case, ${ }^{37}$ the New Zealand Court of Appeal has sidestepped the issue of parliamentary sovereignty posed by orthodox constitutionalism when determining Treaty litigation. ${ }^{38}$ He suggests that sovereignty is kept out of the picture by the Court of Appeal as it is unhelpful and unsuited to the pragmatic nature of the Court's decisions. McHugh's writing focuses on how the indigenisation of constitutional discourse provides an alternative to the concept of unitary parliamentary sovereignty which has previously dominated constitutional thought. McHugh has essentially resiled from his earlier position ${ }^{39}$ that Leviathan ${ }^{40}$ (unitary and indivisible sovereignty) was compatible with tino rangatiratanga under the orthodox legal paradigm. McHugh now acknowledges: ${ }^{41}$

Rangatiratanga and sovereignty: square peg in round hole.

Essentially, McHugh has departed from a strict orthodox legal paradigm and now rejects that a grundnorm based on Leviathan is able to represent the nature of constitutional entity that is New Zealand. McHugh argues that this traditional constitutionalism should be replaced by a contemporary constitutionalism which is "dialogic and aspectival". ${ }^{42}$ Such contemporary constitutionalism would reject Leviathan's "empire of uniformity" and focus on recognising and affirming difference through mutual recognition, consent and cultural continuity. ${ }^{43} \mathrm{McHugh}$ argues that the Court of Appeal has commenced this transformative process with the Treaty decisions. ${ }^{44}$ He concludes: 45

The dominant monologic voice of Leviathan is increasingly unable to suppress the difference which historically (per Binney's Redemption Songs) and contemporarily refuses to succumb and, which, remains teeming with life despite "the empire of uniformity" tending otherwise. That

$37 \quad R v$ Secretary of State, ex parte Factortame (No 2) [1991] AC 603. The House of Lords disapplied an Act of Parliament and dealt with this issue of Parliamentary sovereignty by ignoring it.

38 Above n 35, 522.

39 McHugh The Maori Magna Carta: New Zealand and the Treaty of Waitangi (Oxford University Press, Auckland, 1991) ch 2.

40 Above $\mathrm{n} 3$.

41 Above $\mathrm{n} 35,502$.

42 Above n 35, 524

43 Above n 35, 524.

44 Above $n$ 35, 528 .

45 Above n 35, 528. 
inability will become manifest as Maori continue to negotiate substantial settlements which will bring an accompanying growth in economic and political power.

The jurisprudence underlying McHugh's quest for a gradual transformation from traditional to indigenous constitutionalism is based upon revisionist historiography and the relationship of law and history. McHugh rejects the Whig historiography ${ }^{46}$ which has provided a source of explanation (in addition to law) for Leviathan. This antiWhiggism is strongly influenced by McHugh's location at Cambridge University, a source of anti-whig scholarship. He expressly acknowledges his indebtedness to "Cambridge men". ${ }^{47}$ McHugh's praise of Judith Binney's Redemption Songs ${ }^{48}$ as "the major landmark of New Zealand historiography" 49 highlights his focus on autochthonous anti-Whig historiography.

This focus on anti-Whig historiography is also evident in some of McHugh's earlier work: 50

The signs are that this organic process [constitutional discourse] is growing in a way in which the old Whig beliefs in an absolute, singular sovereign will be challenged.

McHugh shares with Kelsey the jurisprudential goal of slaying the Leviathan. However, this is the limit of their congruence. McHugh's methodology of gradualism from within the orthodox paradigm is rejected by Kelsey as being monocultural and a perpetuation of Pakeha hegemony. ${ }^{51}$ McHugh retorts: ${ }^{52}$

46 Whig historiography views the development of traditional constitutional theory as "a selfcongratulatory tale of pre-ordained growth wherein the past has no option but to produce Leviathan's glorious ... present": above n 35, 515 .

47 Above n 35, at n 26: "The choice of Cambridge has a particular resonance as the influential intellectual figures behind this article, Maitland, Wittgenstein, Herbert Butterfield, Michael Oakeshott, Professors Quentin Skinner, JGA Pocock, James Tully and Andrew Sharp and (we will see) Lord Cooke, PC are all Cambridge men. This is a moment, perhaps, to acknowledge my intellectual gratitude to these figures."

48 Binney Redemption Songs: A Life of Te Kooti Arikirangi Te Turuki (Bridget Williams Books, Auckland, 1995).

49 Above, n 35, 528.

50 McHugh "The Lawyer's Concept of Sovereignty, the Treaty of Waitangi, and a Legal History of New Zealand" in Renwick (ed) Sovereignty and Indigenous Rights: The Treaty of Waitangi in International Contexts (Victoria University Press, Wellington, 1991) 170, 183.

51 Above n 2, 98.

52 Above n 2, 98. 
Such dismissiveness hardly deserves description as a critique, for it absolves its proponents from any form of intellectual engagement with the paradigm except through what is usually superficial and selective scholarship based on a weak to non-existent historical method tailored to reveal the conspiratorial character of Pakeha law and governance. If you look for conspiracies you'll find them.

McHugh, on the basis of his jurisprudence founded on historiography, attacks the "historical stasis" and implicit nihilism of Kelsey's radical commentary: ${ }^{53}$

Unhitched to critical Marxism, the CLS critique would suggest a deconstructed legal system permanently adrift. Tied to the Marxian post, however, the radical critique dismisses most change as perpetuation and continued legitimation of Pakeha hegemony and repression of Maori Treaty rights.

Contrary to Kelsey's "passive revolution", McHugh concludes that the Treaty is coming to permeate the whole of New Zealand society in a way that is organic and more deep-seated than radical writers wish to acknowledge. ${ }^{54}$ As noted by Havemann, ${ }^{55}$ McHugh and Kelsey are "talking past each other" at this point. McHugh argues that Treaty justice is possible through the orthodox legal paradigm and Kelsey focuses on whether such justice is desirable or acceptable.

\section{Jackson}

In contrast to the eurocentric and metropolitan jurisprudence of both Kelsey and McHugh, Moana Jackson is committed to reclaiming the institutions, law, religion and faith of Maoridom from the oppression of Pakeha law. ${ }^{56}$ Jackson utilises the notion of the "Word", 57 which is essentially the paradigm of te ao Maori, the Maori dimension.

Jackson is seeking to reassert the beginning word of Maori, and prevent its subjugation to the alien word of the Pakeha world: 58

53 Above n 2, 104.

54 Above $\mathrm{n}$ 2, 105: "The dismissive view of this change which Kelsey takes is a logical necessity of the intellectual hole dug by her own 'radicalism'".

55 Above n 1, 74.

56 Jackson "The Treaty and the Word: the Colonisation of Maori Philosophy" in Oddie and Perrett (eds) Justice, Ethics and New Zealand Society (Oxford University Press, Auckland,1992) 1, 10.

57 Derived from Harding There is a River: The Black Struggle for Freedom in America (Harecourt Brace Jovanovich, New York, 1981), and utilised by critical race scholars.

58 Above n 56, 1. 
The unacknowledged and denied acts of colonisation flow from the same processes as the acknowledged and admitted. They are all products of a foreign philosophy, a new word introduced into our land - a word born of a Christian God, a capitalist ethic, a common law, an imperial domain, and an individuated manifest destiny. Above all, this new word is born of a cultural and racist arrogance which persists today - now more often covert rather than overt, more often cloaked in the newspeak of bicultural rhetoric or legal pluralism rather than the open bluster of colonialism.

Jackson argues, somewhat apocalyptically, that colonialism will cease, not when Pakeha see the error of their ways (Jackson argues they never will), but when Maori rise up to "reclaim the validity of our own institutions". 59 The cause of such a reclamation is left unstated, and the effect is abstractly described as "a redemption of the hopes expressed so long ago in the first remembered wisdom of our word". 60

The jurisprudence of Jackson, particularly in the context of his analysis of criminal law, ${ }^{61}$ is both critical and instrumental in the extreme: ${ }^{62}$

Law is used as an instrument of socio-racial control and oppression. [emphasis added]

Jackson argues that the structure of New Zealand criminal law is a source of oppression for Maori, and a cause of the all too well known statistics. ${ }^{63}$ The criminal law ignores the Maori perspective on such issues as culpability and harm, and continues to dismiss the tenets of traditional Maori law as incompatible with the legal liberal ideology of egalitarianism. Through this critique of criminal law, Jackson, in contrast to Kelsey, contextualises the critique of legal liberalism.

Although not acknowledged, his work shares many similarities with Critical Race Theory, a recently formed progeny of Critical Legal Studies. The similarities include not only the use of the notion of the "Word"64 and the rejection of legal liberalism, ${ }^{65}$ but also

59 Above n 56, 10.

60 Above n 56, 10.

61 Jackson "Criminality and the exclusion of Maori" (1990) 20 VUWLR, Monograph 3, 23.

62 Above n 61, 24.

63 New Zealand Official Yearbook (GP Publications, Wellington, 1997): Maori life expectancy is five years less than Pakeha; $49 \%$ of women inmates and $45 \%$ of male prison inmates are Maori; only $3.9 \%$ of students obtaining bursary are Maori, whereas $36.6 \%$ of students leaving High School without a qualification are Maori; Maori make up $65 \%$ of admissions to mental health facilities; Maori infant mortality is almost double that of Pakeha; Maori unemployment rates are over triple that of Pakeha.

64 See Lawrence "The Word and the River: Pedagogy as Scholarship as Struggle" (1992) 65 Southern California L Rev 2231. 
the use of personal narrative ${ }^{66}$ and the optimism that change is possible. ${ }^{67}$ The contribution that these conceptual tools could make to the Treaty discourse will be developed in Part V of this paper.

The language of Jackson's attack on legal liberalism resembles the critical Marxism of Kelsey: 68

Pakeha lawyers, judges and institutions such as the Waitangi Tribunal no longer dismiss the concept of rangatiratanga: they simply redefine it as a limited form of property right.

However, the jurisprudential foundations of Jackson and Kelsey are distinct. Kelsey argues the structural inequality of Maori is part of the wider capitalist oppression. In contrast, Jackson is seeking to reassert Maori institutions (such as law) in place of the current monocultural paradigm. Jackson's writing is imbued with a sense of romantic nationalism, he eulogises the social utility of traditional concepts such as $u t u$ (revenge), muru (plunder) and hara (unacceptable acts). This romantic nationalism is evident in his use of the "beginning word", which is strongly reminiscent of the volksgeist of F K Von Savigny. ${ }^{69}$ To condense Jackson's jurisprudence into that of Kelsey's is to collapse both indigenous and eurocentric arguments into the carry-all label of "radical".

\section{Brookfield}

The fourth perspective on the Treaty discourse to be considered in this paper is that of Professor F M Brookfield, an orthodox voice that probably expresses views held by the majority of the profession, if not the Pakeha public at large.

Brookfield argues that it cannot be contested that the Crown took more than it was given under the Treaty of Waitangi. ${ }^{70}$ Accordingly, he asserts that in effect the Crown

65 Hayman \& Levitt "The Tales of White Folk: Doctrine, Narratives and the Reconstruction of Racial Reality" (1996) 84 California L Rev 377.

66 Williams "Alchemical Notes: Reconstructing Ideals from Deconstructed Rights" (1987) 22 Harvard Civil Rights - Civil Liberties L Rev 401.

67 Above n 64, 2296.

68 Above $\mathrm{n} 56,9$.

69 Von Savigny argued that a legal system is a subset of culture, and accordingly the origin of law is to be found in a people's national spirit (volksgeist). This theory optimistically assumes that peoples and nations are unitary entities. Von Savigny utilised this concept of volksgeist to reject calls for the codification of the German legal system. See Kantorowicz "Savigny and the Historical School of Law" (1937) 53 LQR 326.

70 Brookfield "The Treaty, the 1840 Revolution and Responsible Government" (1992) 5 Canta L R 59, 62. 
assumed sovereignty in New Zealand by revolution. Crown sovereignty was legitimated through time and the effective assertion of power. Brookfield argues that via the revolutionary principle what was de facto became de jure. ${ }^{71}$

Brookfield is not proposing the "red neck" conclusions of The Travesty of Waitangi ${ }^{72}$ or the ultra-conservative position of Guy Chapman. ${ }^{73} \mathrm{He}$ is seeking to place the Treaty discourse into the referential framework of black letter constitutional law.

The jurisprudence of Brookfield in asserting the revolutionary principle falls clearly within the legal liberal orthodoxy. The rule of law is described as an "unqualified good". 74 Brookfield's detailed analysis of constitutional case law presupposes that legal reasoning is not viewed as merely indeterminate political discourse. Brookfield's argument is based on the foundation of Parliament being a unitary and indivisible Leviathan. Clearly, the jurisprudence of Brookfield conflicts with the critical jurisprudence of Kelsey and Jackson.

Brookfield reviews the "legal merits" of Kelsey's work, and her thesis of "passive revolution" (not to be confused with the "revolutionary principle" of Brookfield) and concludes: ${ }^{75}$

All this is by no means to impugn entirely Ms Kelsey's handling of legal material in the writings reviewed. However, the reader who admires her great skill in dealing with and organising masses of facts could wish that ideological concerns and purposes, or perhaps sesquicentennial haste to publish, did not at times appear to affect so heavily her treatment and exposition of the law.

This conclusion is another example of the orthodox talking past the radical. Brookfield analyses in detail the early Treaty cases without ever addressing the ideological issue that concerns Kelsey: what is the role of law in society and in particular

71 Above n 18, 416 .

72 Scott The Travesty of Waitangi: Towards Anarchy (Campbell Press, Dunedin, 1995).

73 Chapman "The Treaty of Waitangi - Fertile Ground for Judicial (and Academic) Myth Making" [1991] NZLJ 228; and reply by McHugh "Constitutional Myths and the Treaty of Waitangi" [1991] NZLJ 316.

74 Above n 18, 415, quoting E P Thompson Whigs and Hunters: The Origins of the Black Act (Peregrine Books, London, 1975) 267. Thompson, a marxist historian, acknowledges the mystifying and hegemonic function of law, but states that "the rule of law itself, the imposing of effective inhibitions on power and the defence of the citizen from powers all-intrusive claims, seems to me to be an unqualified human good". See above at 266 .

75 Above n 18, 413. 
what role has law played in denying Maori tino rangatiratanga? This communication divide leads Brookfield to state: ${ }^{76}$

It is necessary in Ms Kelsey's [case] to penetrate beyond the often counter-productive polemic

of much of her work.

He ignores the fact that the "counter-productive polemic" is actually the point of Kelsey's writing. Kelsey is attempting through her demystification of legal liberalism to initiate a counter hegemonic revolution, thus her "counter-productive polemic" is in fact the raison d'être of her thesis. This polemic is of course centred around Kelsey's view that the relationship between government, law and the interests of Pakeha and capital is not linear, but always in the long term interests of Pakeha capital. ${ }^{77}$

\section{E Summary}

This part of the paper has provided a brief overview of four differing perspectives on the Treaty discourse and examined the jurisprudence underlying these perspectives. It is clear from this preceding analysis that the work of both Kelsey and Jackson indicates some reliance on, and subscription to, what may be generically termed critical jurisprudence. However neither has articulated the critical jurisprudence underpinning their work in any meaningful way. In effect, the Treaty discourse has only "scratched the surface" of the critical jurisprudential developments of the past two decades.

It is evident however, that the introduction of such critical jurisprudence is vehemently opposed by McHugh and Brookfield, who view such radicalism as throwing the legal baby out with the Treaty bath water. This conflict raises the issue of how a more complete autochthonous critical jurisprudence would impact upon the Treaty discourse. To answer this question it is necessary to examine in greater detail the fundamental tenets and orthodox critique of both Critical Legal Studies and Critical Race Theory.

\section{CRITICAL LEGAL STUDIES}

\section{A Critical Legal Studies}

The CLS movement has mounted a full frontal assault on the edifice of modern jurisprudence. ${ }^{78}$ In order to explore the fundamental tenets and consequential critique that comprises this "assault" it is necessary to examine the origins of CLS.

76 Above $\mathrm{n} 18,419$

77 Above n 11, 68.

78 Hutchinson and Monahan "Law, Politics and the Critical Legal Scholars: the Unfolding Drama of American Legal Thought" (1984) 36 Stanford L Rev 199. 
CLS is not a homogeneous and discrete school of jurisprudential thought. This lack of unity is most pronounced when CLS scholars attempt to describe the purpose of CLS. Peter Gabel describes the project of CLS as being "to realise the unalienated relatedness that is immanent within our alienated situation". ${ }^{79}$ Duncan Kennedy (another leading CLS scholar) responds that this is "abstract bullshit". ${ }^{80}$ Kelman supports Kennedy by noting that it is difficult to know whether Gabel is actually describing a blissful state of mind or a small household appliance. ${ }^{81}$ Accordingly, the most that can be said in relation to the purpose of CLS is that it is: 82

A political location for a group of people on the Left who share the project of supporting and extending the domain of the Left in the legal academy.

This "political location" has however been derived from a mixture of earlier intellectual movements, particularly legal realism, law in society and critical Marxism. The primary influence in the formation of CLS is legal realism. This influential jurisprudential school was developed in America in the 1930s by Karl Llewellyn, Felix Cohen and Jerome Frank. Legal realism rejected both formalist attempts to derive "correct" legal doctrine from basic principles and "correct" results from legal doctrine. It rejected as vacuous and circular the traditional legal analysis that was exemplified by the writings of Christopher Columbus Langdell ${ }^{83}$ and the decisions of the Lochner era of Supreme Court of the United States. ${ }^{84}$ Such formalism held that judges did not make law, but merely applied law that had been created by legislation or that was immanent within the common law: ${ }^{85}$

Every judicial act resulting in a judgment consists of a pure deduction.

79 Above n 30, 1

80 Above n 30, 1.

81 Kelman "Trashing" (1984) 36 Stanford L Rev 293, 343.

82 Above n 19, 1517.

83 Langdell "Classification of Rights and Wrongs" (1899) 13 Harvard L Rev 537; Langdell "Mutual Promises as Consideration for Each Other" (1900) 14 Harvard L Rev 496; Patterson "Langdell's Legacy" (1995) 90 Northwestern University L Rev 196.

84 The Lochner era was a period at the start of the twentieth century during which the Supreme Court regularly struck down social welfare legislation as unconstitutional: See Lochner v New York 198 US 45 (1905) and Coppage v Kansas 236 US 1 (1915). The case of West Coast Hotel v Parish 300 US 370 (1937) signalled the end of the Lochner era.

85 Zane "German Legal Philosophy" (1918) 16 Michigan L Rev 287, 338. 
Legal realism argues that this formalist analysis is the result of manipulation of abstract labels and categories. ${ }^{86}$ The indeterminacy critique is the bequest of legal realism to CLS:87

The work of the critical legal scholars can be understood as the maturation of .... Realist

Methodologies - a maturation in which critical scholars explore incoherence at the level of

social or political theory, and critical scholarship is linked not to reformist policy programmes,

but to a radical political agenda.

To the methodologies of legal realism, CLS has added the critical philosophies of Antonio Gramsci, Max Horkheimer, Herbert Marcuse, Jurgen Habermas and Jean-Paul Sartre. ${ }^{88}$ The consequential "political location" is examined in detail in Part III B of this paper.

It is useful to consider the history of CLS, which commenced in the anti-establishment period of post-Vietnam America. The first conference of CLS scholars was held in Madison, New York in 1977. This conference was organised by David Trubek, Duncan Kennedy and Mark Tushnet and the invitation stated: ${ }^{89}$

Law is an instrument of social, economic and political domination, both in the sense of furthering the concrete interests of the dominators and in legitimating the existing order.

Personal relationships also played an important role in the formation of CLS. Kennedy, Trubek and Tushnet were all at Yale Law School between 1967 and 1972 (together with other CLS scholars, Abel, Gertner, Heller and Rosenblatt) and Kennedy and Morton Horwitz were at Harvard Law School together from 1974 to 1984 (together with Klare, Kelman and Stone). ${ }^{90}$ These two concentrations of critical scholars have provided the intellectual firepower (in addition to Roberto Unger's seminal Knowledge and Politics ${ }^{91}$ ) necessary to commence the attack on mainstream legal liberalism.

Twenty years after the first CLS conference, the tenets of CLS have formed the foundation of critical feminist jurisprudence and critical race theory. In addition, the movement has expanded from the ivory towers of Yale and Harvard to recolonise

86 Price "Taking Rights Cynically: A Review of Critical Legal Studies" (1989) 48 C L J 271, 279.

87 Jabbari "From Criticism to Construction in Modern Critical Theory" (1992) 12 OJLS, 507, 509.

88 Above n 21,361.

90 Above $\mathrm{n} 89,415$.

91 Unger Knowledge and Politics (Free Press, New York, 1976). 
continental jurisprudence $^{92}$ and inform academic writings throughout the English speaking world. ${ }^{93}$

\section{B Fundamental Tenets}

This part of the paper examines the fundamental tenets of the CLS attack on legal liberalism: indeterminacy, legitimation and false consciousness. In addition the application of this critique to the legal concept of rights and the CLS alternatives to legal liberalism will be considered.

The indeterminacy critique, the legacy of legal realism, can be summarised as: ${ }^{94}$

Law is simply politics in different garb: it neither operates in a historical vacuum nor does it exist independent of ideological struggles in society.

This is not to say that CLS is merely flogging the dead horse of Langdellian formalism. Most lawyers would acknowledge that such formalism is moribund. The CLS critique refuses to hedge on the indeterminacy of the law, it refuses to accept that there is good or bad legal reasoning, ${ }^{95}$ it holds there is no interesting difference between legal discourse and political or moral discourse. To adapt Clausewitz: ${ }^{96}$

[Law] is the continuation of political discourse by another means.

Hutchinson and Monahan provide a simple illustration of the indeterminacy critique in relation to product liability law. ${ }^{97}$ The law chooses between a broad variety of options, with one extreme being no liability for manufacturers except for contractual terms, and the other being absolute liability for harm caused by products. Although neither extreme

92 Above $\mathrm{n} 87$.

93 Drahos and Parker "The Indeterminacy Paradox in Law" (1991) 21 Western Australian L R 305 (Australia); Meyerson "Fundamental Contradictions in Critical Legal Studies" (1991) 11 OJLS 439 (South Africa); above n 21 (New Zealand).

94 Above $\mathrm{n} 78,206$.

95 In contrast to the majority of mainstream academic writing which is premised on the rationality of the law: For example Stone "Judicial Activism or Judicial Restraint? The Divergence of Opinion Between the Privy Council and the New Zealand Court of Appeal in Commercial Cases. Retention or Abolition." Unpublished Paper, submitted in partial completion of LLM, 22 April 1997, at 8: "[Decisions] must be predictable if the judiciary are to engender confidence in their legal reasoning...." [emphasis added].

96 Keegan A History of Warfare (Hutchinson, London, 1993) 3, quoting Clausewitz On War (tr. Howard and Panet, Princeton, 1976): "War is a continuation of political discourse [des politischen verkehers] by another means".

97 Above n 78, 210. 
is favoured, the location of product liability law on this spectrum cannot be determined objectively by legal logic or policy analysis. Resolution of the conflict between the individual (absence of liability) and the community (absolute liability) is no more than an arbitrary choice. This analysis of product liability law is typical of CLS methodology. Through a series of historical and contemporary studies, the CLS scholars have sought to demonstrate that the legal process at large and its discrete doctrinal components, such as contract, tort, constitutional law, labour, criminal law, and the like, are fundamentally indeterminate and manipulable. ${ }^{98}$

Of particular concern to CLS scholars is the effect of this indeterminacy on legal education: ${ }^{99}$

Teachers convince students that legal reasoning exists, and is different from policy analysis, by bullying them into accepting as valid in particular cases arguments about legal correctness that are circular, question begging, incoherent and so vague as to be meaningless.

The second fundamental tenet of CLS is to demystify the legitimating effect of legal liberalism. This part of the CLS critique relies on the critical Marxist tools of ideology, hegemony and false consciousness: ${ }^{100}$

The legal system (including legal doctrine) buttresses the hegemony of the capitalists by propagating a range of everyday ideas about property and contract as well as a range of broader notions about individual rights and the rule of law.

CLS Scholars argue that the ideology of legal liberalism confers on legal doctrine a false air of naturalness and results in unjust social structures acquiring the appearance of inevitability. For the critical scholars, legal consciousness is a cerebral tool for the suppression of time: it is a device to hide or deny the fundamental truth that everything is in a process of changing or becoming. ${ }^{101}$ To CLS scholars the current status quo is merely a temporary truce in social conflict masquerading as the inevitable outcome of such conflict.

98 Above n 78, 211.

99 Above n 78, 212: quoting Kennedy "Legal Education as Training for Hierarchy" in Kairys (ed) The Politics of Law: A Progressive Critique (Pantheon Books, New York 1982) 40, 46.

100 Above n 86, 289.

101 Above n 78, 217. 
CLS scholars argue that individual rights are the embodiment of this process of legitimation and false consciousness. Individual rights are viewed by CLS scholars as "passivising illusions": 102

People don't realise what they're doing is recasting the real existential feelings that led them to become political people into an ideological framework that co-opts them into adopting the very consciousness they want to transform.

Exactly what people don't need is their rights. What they need are the actual forms of social life that have to be created through the building of movements that can overcome illusions about the nature of what is political, like the illusion that there is an entity called the state, that people possess rights.

This rejection of rights as enervating is the fundamental distinction between CLS and Critical Race Theory, and will be addressed in detail in Part IV.

As can be seen above, the vast majority of CLS scholarship focuses on the critique of legal liberalism through the methodology of deconstruction or "trashing". Such methodology is aimed at exposing illegitimate hierarchies, particularly those within legal education. Kelman attacks the hierarchy between professor and student, which he argues is illegitimate given the indeterminacy of the law: ${ }^{103}$

Law professors are, in fact, a kiss away from panic at every serious, self-conscious moment in which they don't have a bunch of overawed students to kick around.

A more detailed attack on the hierarchies of legal education is contained in Kennedy's infamous article ${ }^{104}$ which proposed that all the staff at Harvard Law School regularly rotate jobs and receive equal remuneration. The orthodox response that the janitor could not teach contract law is dismissed by Kennedy on the basis that contract law (as with all law) is wholly indeterminate anyway. Such "trashing" is subject to heavy orthodox criticism (detailed in Part III C of this paper), but defended by CLS scholars on the grounds that: 105

One must start by knowing what is going on, by freeing oneself from the mystified delusions embedded in our consciousness by the liberal legal view of the world.

102 Above n 30, 26 and 33.

103 Above n 81, 322

104 Kennedy "Legal Education as Training for Hierarchy" in Kairys (ed) The Politics of Law: A Progressive Critique (Pantheon Books, New York, 1982) 40.

105 Freeman "Truth and Mystification in Legal Scholarship" (1981) 90 Yale L J 1229, 1230. 
Essentially the CLS scholars argue that the trashing of legal liberalism is necessary before an alternative structuring of human relations can be envisaged. A few CLS scholars have, however, attempted to provide an alternative vision of how society should be structured. ${ }^{106}$ The most comprehensive of these is the "structure of no structure" proposed by Unger. ${ }^{107}$

Unger's utopian vision is based on a commitment to ensuring social arrangements are continually contested and not permitted to reify into unjust hierarchies as has occurred under legal liberalism. To this end Unger proposes four kinds of rights: ${ }^{108}$

(a) Immunity rights: which protect individuals from interference and domination;

(b) Destabilisation rights: which entitle individuals to demand the disruption of established institutions;

(c) Market rights: which replace property rights and give a conditional claim on divisions of social capital; and

(d) Solidarity rights: which foster mutual reliance, loyalty and communal responsibility.

This "structure of no structure" is designed to prevent the reification of social struggle into hierarchies that are then justified by such social constructs as the invisible hand of the free market. Unger is seeking to ensure that there is continual debate over, and experimentation with, different forms of social life.

\section{Orthodox Response to Critical Legal Studies}

The orthodox response to the jurisprudential attack of CLS has been vigorous, and at times vitriolic. ${ }^{109}$ The response has focused not only on the conceptual tools of CLS, indeterminacy and legitimation, but also on the more fundamental issue of what, if anything, does the CLS critique achieve.

\footnotetext{
106 See Frug "The City as a Legal Concept" (1980) 93 Harvard L Rev 1059 and Klare "Critical Theory and Labour Relations Law" in above n 81, 65.

107 Unger "The Critical Legal Studies Movement" (1983) 96 Harvard L Rev 561.

108 Above n 107, 599-600.

109 Above n 89, 455: "CLS is a fountain of confusion".
} 
Legal liberal scholars dismiss the CLS indeterminacy critique as "almost passé", 110 and in any event greatly overstated: ${ }^{111}$

The indeterminacy thesis stakes out an extreme position, and one that is almost trivially easy to disprove.

The response of orthodox scholars centres upon easy cases; if a man threatens someone with a gun and demands money, he has committed armed robbery. No question. Essentially the orthodox scholars are accepting a degree of indeterminacy in the law but contest the absolutist position of CLS, and in the alternative, contest the CLS position in relation to the effect of indeterminacy in the law. McHugh argues that such indeterminacy is in fact beneficial as it permits "dynamism and responsiveness" in the common law. ${ }^{112}$

The second conceptual tool rejected by the orthodox scholars is that of legitimation or false consciousness. The focus of this response is that CLS imbues the law with a persuasive strength that is non-existent, and accordingly ignores other forms of social control or legitimation. At the heart of the orthodox response to the CLS legitimation thesis is a rejection of the paternalistic self-estrangement view of human nature implicit in such a thesis: ${ }^{113}$

According to this way of thinking, humans are fallen creatures who have become blinded to their true situation and have lost their way, and who have consequently created forms of life which are frustrating and unsatisfying. But it holds out the hope that if humans throw off their blinders and come to understand their nature and their true needs and capacities they can liberate themselves from their shackles, can reconnect to the sources of vitality and health available to them, and can refashion their lives so that they are full and happy.

This world view is rejected by both orthodox and CRT scholars (for different political purposes) as naïve ${ }^{114}$ and discordant with the reality of oppressed sectors of society: ${ }^{115}$

110 Hasnas "Back to the Future: From Critical Legal Studies Forward to Legal Realism, or how not to miss the point of the indeterminacy argument" (1995) 45 Duke L J 84, 86: "The dispute over the indeterminacy argument, and to some extent the Crits themselves, are regarded as passé".

111 Above n 86, 284.

112 Above n 2, 99.

113 Fay Critical Social Science: Liberation and its Limits (Polity Press, Cambridge, 1987) 10.

114 Above n 89, 426.

115 Above n 86, 291. 
The segregation of buses, trains, and public schools was long required by state law, but that plainly did not lead blacks to think it was legitimate.

The orthodox conclusion is that the CLS scholars have again overplayed their hand, law is merely one of many factors that impact upon people's conception of what is justice.

However, the primary orthodox criticism of CLS scholarship is the lack of a positive programme to replace the "trashed" ideology of legal liberalism: ${ }^{116}$

If their work is not to be consigned to the dustbin of history, they must seek to translate their theories into some attainable dimensions of human experience.

The CLS rejoinder is that they are under no obligation to offer an alternative to legal liberalism. Kelman suggests that the vast majority of mainstream legal academics must "have been told (repeatedly) by their moms and dads, 'If you don't have anything nice or constructive to say, say nothing at all."'117 CLS scholars view it as their legitimate role as academics to "trash" and question the dominant hierarchy without a contemporaneous responsibility to suggest a replacement. In New Zealand this role of academics as social critics is enshrined in statute. Section 161 of the Education Act 1989 states the purpose of universities is to enhance academic freedom, including the ability "to question and test received wisdom, to put forward new ideas and to state controversial or unpopular opinions". Nowhere in the Education Act are academics required to put forward alternatives to the objects of their criticism.

When a positive programme is offered by a CLS scholar, such as Unger's "structure of no structure", it is rejected as being so vague as to be "atmospheric". ${ }^{118}$ In addition, orthodox scholars turn the critical tools of CLS on the CLS positive programmes in order to prove that such programmes are no more valid than the debunked legal liberalism that CLS is seeking to replace. Any replacement of legal liberalism requires a normative justification if it is to avoid merely being another form of ideology. Without such a justification any positive programme would be subject to the identical attack that CLS has launched against legal liberalism. The "structure of no structure" would, for example, replace "legal liberalism" in the critiques. However, critical theory rejects the possibility of such normative justifications. In effect any positive CLS programme requires a rejection

116 Above $n$ 78, 227.

117 Above n 81, 297.

118 Above n 86, 292. 
of the basic CLS commitment to the contingent nature of social relations. As Hutchinson and Monahan conclude: ${ }^{119}$

CLS is ultimately hoisted by its own critical petard.

In summary, it is submitted that the force of these orthodox responses is persuasive, and the initial attack of CLS has certainly been repulsed. The CLS indeterminacy and legitimation theses have, in the author's opinion, been overstated. The latter relies on a optimistic view of human nature that is divorced from the experiential reality of those people and groups that CLS scholars are claiming to assist. This is not to dismiss the critique of legal liberalism, undoubtedly CLS has made an indelible mark on traditional jurisprudence. Critical legal studies has provided the foundation from which critical jurisprudence has been able to expand in the 1990s. It is to one of these critical progeny, Critical Race Theory, that this papers now turns.

\section{CRITICAL RACE THEORY}

\section{A Relationship with Critical Legal Studies}

Critical Race Theory ("CRT") is a new form of critical jurisprudence that, along with critical feminism, has emerged in the past decade from the shadow of CLS. The development of CRT has been caused primarily by CLS's failure (and at times refusal) to develop a positive programme, and the dismissive critique of rights discourse to which CLS scholars subscribe.

The raison d'être of CRT is that, notwithstanding the indeterminacy of rights discourse, rights should not be "trashed" as they serve as an essential tool of political cohesion and more importantly as a source of self-empowerment. ${ }^{120}$ Rights enable minorities to rise up from the referential range of "object" to that of "subject". CRT scholars are not seeking to totally invalidate the CLS critique of rights, but are seeking to strip it of its paternalistic assumptions, and introduce their own subjective experience to the critique: ${ }^{121}$

In short, the two groups see rights differently. White CLS members see rights as oppressive, alienating and mystifying. For minorities, they are invigorating cloaks of safety that unite us in a common bond. Instead of coming to grips with the different function of rights for the two

119 Above n 78, 233.

120 Above n 66, 414.

121 Delgado "The Ethereal Scholar: Does Critical Legal Studies Have What Minorities Want?" (1987) 22 Harvard Civil Rights - Civil Liberties L Rev 301, 306. 
groups, Crits insist that minorities adopt their viewpoint, labeling disagreement on our part false consciousness or a lack of political sophistication.

This difference in the experimental reality of rights is highlighted by Williams when recalling her and Peter Gabel's different approaches to apartment hunting. ${ }^{122}$ Gabel on finding an apartment handed over $\$ 900$ in cash to strangers with no lease or keys, relying instead on the stranger's word to return at the agreed time. By contrast, although Williams was moving into an apartment in a building owned by friends, she signed a detailed legalistic lease as an arm's length transactor. Both Gabel and Williams wished to foster a relationship and build trust. Gabel did this through informality, self consciously abandoning his power as a white, male law professor. Williams recalls that she was acutely conscious of her "black femaleness" and sought to overcome this estrangement through raising herself to a commercial equal.

This story is used by Williams to highlight the fundamentally different views of rights held by minorities and the white males who make up the bulk of CLS scholars. CLS scholars may well believe that rights are contradictory, indeterminate, reified and marginally decisive in social behaviour, ${ }^{123}$ but they do so from the position of rightsempowered white male academics. This rejection of formality is in minorities' experience overly sanguine. For the historically disempowered, the conferring of rights is symbolic of all of their previously denied aspects of humanity. ${ }^{124}$

Unlike CLS the project of CRT is redemptive, not deconstructive. It is in essence a movement seeking racial justice in the context of racist America. This jurisprudential attack on racism is based upon the experience of centuries of oppression, of being objects rather than subjects. Accordingly, CRT scholars reject the false consciousness tenet of CLS: 125

Is not "false consciousness" an excuse for white radicals to assert and maintain power they

would otherwise have to explain and justify.

This rejection is part of the wider anti-intellectualism of CRT that further separates it from CLS. As noted by one commentator, CRT scholars had hovered around the CLS table, never invited to dine lest they use the wrong "intellectual fork". ${ }^{126}$ CRT is primarily

122 Above n 66, 406.

123 Above n 66, 404: quoting Trubek "Where the Action is: Critical Legal Studies and Empiricism" (1984) 36 Stanford L Rev 575, 578.

124 Above n 66, 414.

125 Above n 121, 312.

126 Dalton "The Clouded Prism" (1987) 22 Harvard Civil Rights - Civil Liberties L Rev 435, 439. 
concerned with the non-intellectual task of ensuring the voice of the silent is heard in the legal academy, and is accordingly able to infiltrate the law. CRT scholars are seeking to utilise law to create a world in which it is possible to realise the dreams of Martin Luther King Jr: ${ }^{127}$

I have a dream that one day this nation will rise up and live out the true meaning of its creed....

I have a dream that one day on the red hills of Georgia, the sons of former slaves and the sons of former slave owners will be able to sit down together at the table of brotherhood...

I have a dream that my four little children will one day live in a nation where they will not be judged by the color of their skin but by the content of their character.

These "dreams" provide the heart of the CRT project. In seeking to provide this "voice" for minorities whose experience continually reinforces that they are not equal or worthy of merit, CRT attacks the cloak of neutrality and inevitability which the law and legal education drapes over the concepts of equality and merit. ${ }^{128}$ CRT scholars argue that merit does not result from the recognition of natural superiority, but from the arbitrary ordering of culturally constructed differences, of social, economic and political advantages and disadvantages. ${ }^{129}$

CRT scholars also attack the myth of equality which enables the cultural background or context in which laws operate to be ignored, ${ }^{130}$ thereby reinforcing existing hierarchies. CRT seeks to contextualise and particularise the law from an unashamedly subjective perspective in order to transform the racial exclusivity of the law, society and legal education. ${ }^{131}$

\section{B Narrative Methodology}

An integral part of the subjective perspective of CRT is the methodology by which the concepts of legal liberalism are challenged. CRT makes extensive and creative use of narrative, story-telling and allegory in conveying the message of the Word: ${ }^{132}$

127 Above n 64, 2291 quoting Martin Luther King Jr.

128 Above n 65, 402.

129 Above n 65, 403.

130 Above n 65, 407.

131 Brown "The Tower of Babel, Bridging the Divide Between Critical Race Theory and Mainstream Civil Rights Scholarship" (1995) 105 Yale LJ 513, 516.

132 Above n 64, 2238. 
The Word is an articulation and validation of our common experience. It is a vocation of struggle against dehumanisation, a practice of raising questions about reasons for oppression, an inheritance of passion and hope.

The seminal example of this creative use of narrative to articulate the Word is Williams' explanation of the relationship of CLS and CRT in "The Brass Ring and the Deep Blue Sea":133

\section{THE BRASS RING AND THE DEEP BLUE SEA}

\section{The Meta-Story}

Once upon a time, there was a society of priests who built a Celestial City whose gates were secured by Word-Combination locks. The priests were masters of the Word, and, within the City, ascending levels of power and treasure became accessible to those who could learn ascendingly intricate levels of Word Magic. At the very top level, the priests became gods; and because they then had nothing left to seek, they engaged in games with which to pass the long hours of eternity. In particular, they liked to ride their strong, sure-footed steeds, around and around the perimeter of heaven: now jumping word-hurdles, now playing polo with the concepts of the moon and of the stars, now reaching up to touch that pinnacle, that fragment, that splinter of Refined Understanding which was called Superstanding, the brass ring of their merry-go-round.

In time, some of the priests-turned-gods tired of this sport, denounced it as meaningless. They donned the garb of pilgrims, seekers once more, and passed beyond the gates of the Celestial City. In this recursive passage, they acquired the knowledge of Undoing Words.

Beyond the walls of the City lay a Deep Blue Sea. The priests built themselves small boats and set sail, determined to explore the uncharted courses, the open vistas of this new and undefined domain. They wandered for many years in this manner, until at last they reached a place that was half a circumference away from the Celestial City. From that point, the City appeared as a mere shimmering illusion; and the priests knew that at last they had reached a place which was Beyond the Power of Words. They let down their anchors, the plumb lines of their reality, and experienced godhood once more.

The Story

Under the Celestial City, dying mortals call out their rage and suffering, battered by a steady rain of sharp hooves whose thundering, sound-drowning path described the wheel of their misfortune.

133 Above n 66, 401. 
At the bottom of the Deep Blue Sea, drowning mortals reached silently and desperately for drifting anchors dangling from short chains far, far overhead, which they thought were lifelines meant for them.

Other examples of narrative include the personal experience of Williams and Gabel apartment hunting ${ }^{134}$ (referred to in Part IV A), the allegory and counter-stories of Delgado's Rodrigo Chronicles, ${ }^{135}$ and "agony stories". One such "agony story" is Professor Harris's harrowing tale of her grandmother "passing"136 to enable her to work in a department store that prohibited Blacks. Only by this self-denying process of "passing" was she able to ensure her family's survival in the depression. ${ }^{137}$ It is this methodology that has attracted the majority of orthodox criticism rather than the substance of the CRT message.

CRT scholars argue that story-telling is a unique method for recognising the plural truths of lived experience, and for reimagining the possibilities of a more compassionate world. $^{138}$ Stories accordingly challenge the legal liberal epistemology that truth is singular. Williams provides a personal narrative highlighting the plural and partial nature of truth: ${ }^{139}$

One summer when I was about six, my family drove to Maine. The highway was very straight and hot and shimmered darkly in the sun. My sister and I sat in the back seat of the Studebaker and argued about what color the road was. I said black. My sister said purple. After I had successfully harangued her into admitting it was indeed black, my father gently pointed out that my sister still saw it as purple. I was unimpressed with the relevance of that at the time, but with the passage of years, and much more observation, I have come to see overheated highways as slightly more purpley than black.

Although each such narrative is unique, the methodology can typically be distinguished by four features: 140

134 Above n 66, 408.

135 New York University Press, New York, 1995: A fictional account of a series of conversations between Rodrigo Crenshaw, a law graduate and his Professor (Delgado).

136 Altering her appearance so as to pass as a white woman.

137 Harris "Whiteness as Property" (1993) 106 Harvard L Rev 1709, 1710.

138 Above n 65, 399.

139 Above n 66, 410.

140 Above n 65, 399. 
(a) Partiality: CRT scholars make no pretence at neutrality, nor are the stories the "whole truth" as such a notion is not believed to be accessible;

(b) Subjectivity: The stories are a celebration of subjectivity, an insistence on the importance of voice and perspective;

(c) Realism: The stories are real whether they are offered as fact or fantasy, they are populated by the richness of human experience; and

(d) Personal: The stories are personal, and are not about the atomistic individual who treads the barren, dehumanised terrain of traditional legal texts.

The purpose of such methodology is to engage the reader more effectively, to encourage connection between the storytellers, the listeners and the subjects of stories. The narrative methodology enables the reader, on the basis of the reader's own social reality, to formulate an interpretation that is independent of the interpretation of others. As noted by one commentator: ${ }^{141}$

[S]tories express depth and complexity. They allow for ambiguity, multiple interpretation, and refracted images. The reader or listener can be convinced and moved, by intellect and emotion. And stories are not exclusive property. One story invites another as people's words weave the tapestry of human connection. [Original emphasis]

CRT is accordingly able to break through the "esoteric terminology and nearly impenetrable style of prose ${ }^{1142}$ that afflicts CLS scholarship. The issue is whether CRT has sacrificed doctrinal analysis in its search for its transformative potential.

\section{Orthodox Critique}

Unlike CLS, orthodox critique of CRT is sparse and focuses on a critique of the narrative methodology as a form of scholarship. Cohen, a black orthodox critic, argues that mainstream scholarship has given CRT a wide berth for fear that others will impugn the motive of racism to their criticism. ${ }^{143}$ Consequently, Cohen argues that CRT has become an "academic ghetto in which the quality of intellectual discourse is suspect". ${ }^{144}$

The fact that storytelling is both interesting and effective is not contested. What is contested by mainstream scholars is whether it is a form of doctrinal analysis, and what

141 Above n 64, 2279, quoting Sara Lawrence Lightfoot "Balm in Gilead: On Love, Justice and the Word", speech presented to the Equal Rights Advocates Annual Luncheon (June 15, 1988).

142 Above n 86, 272.

143 Cohen "A Different Black Voice in Legal Scholarship" (1992) 37 NYL Sch L Rev 301.

144 Above n 143, 301. 
standards should be applied in evaluating narrative. Litowitz argues that storytelling is merely public comment, and that legal commentators must do more than listen to and recount stories. Stories must be filtered through the framework of legal doctrine. ${ }^{145}$ A failure by minority scholars to do so could result in the stereotyping of minority law professors as specially endowed with storytelling abilities but not with analytical skills.

Integral to the narrative methodology is the unabashed subjectivity of much of the CRT scholarship. This subjectivity leads to a claim by some CRT scholars that the minority victims of hierarchy have a "special voice" and "distinctive insights". ${ }^{146}$ Orthodox scholars reject this distinctiveness thesis: ${ }^{147}$

For a number of minority jurisprudence school authors ... personal experience functions like an incantation recited to magically endow the writer with special standing rather than as a device to make the human impact of a regime more real to the reader.

This criticism is not aimed at the use of narrative per se, but rather at the quality of its use by CRT scholars.

Cohen does not believe that the use of narrative should excuse CRT scholars from an application of the standards of soundness and persuasiveness, ${ }^{148}$ standards that Cohen argues are often lacking. ${ }^{149}$ Litowitz agrees that, in the event of a failure to apply qualitative standards to the normative methodology, minority jurisprudence becomes a very easy game to play. ${ }^{150}$ All that is needed is a personal trait (in his case Jewishness) and hurtful experiences. He caustically concludes: ${ }^{151}$

But we must ask where these stories and narratives lead in the law, especially constitutional

law. The answer is nowhere.

Ultimately, the orthodox criticisms are reducible to arguments of merit. The orthodox scholars therefore fail to engage CRT, which has already rejected the notion of merit. Accordingly, such criticism does little to affect the CRT project of creatively articulating the Word. The discourse between CRT and orthodox scholars lacks any points of

145 Litowitz, "Some Critical Thoughts on Critical Race Theory" (1997) 72 Notre Dame L Rev 503, 521.

146 Matsuda, "Looking to the Bottom: Critical Legal Studies and Reparations" (1987) 22 Harvard Civil Rights - Civil Liberties L Rev 323, 326.

147 Above n 143, 316.

148 Above n 143, 308.

149 Above n 143, 322.

150 Above n 145, 517.

151 Above n 145, 518. 
common reference and results in both CRT and orthodox scholars preaching to the converted.

A more engaging critique is proposed by Eleanor Brown. ${ }^{152}$ She argues that the paradigm of racism utilised by CRT scholars is too simplistic for mainstream scholars to recognise themselves in the stories told. She argues that the underlying CRT premise, of endemic dominative racism, must be modified so as to incorporate the schizophrenic theory of racism proposed by the social science research. ${ }^{153}$ This research indicates that, although negative stereotyping of minorities is declining, white attitudes on racism unconsciously fluctuate between focusing on structural issues (such as living conditions) and behavioural issues (such as crime). ${ }^{154}$ Only once CRT adopts a more sophisticated model of racism will the communication that is necessary for CRT to have transformative potential occur.

\title{
V AUTOCHTHONOUS CRITICAL JURISPRUDENCE
}

\section{A Critical Legal Studies and the Treaty Discourse}

The final issue is how the conceptual tools of CLS could be applied in the context of the Treaty discourse, and whether such application would contribute to the development of an autochthonous critical jurisprudence capable of realising a post-colonial New Zealand.

Unlike Kelsey, a "true" CLS critique of the Treaty discourse would seek to deconstruct or trash particular "victories" achieved in the past decade, for example, the allocation of individual transferable quota to Maori under the Treaty of Waitangi (Fisheries Claims) Settlement Act 1992. It is suggested that such a critique would focus on how the legislation has legitimised individual property rights and dismissed the communityoriented philosophy of Maori culture.

A second possible autochthonous CLS critique would highlight the indeterminacy of Treaty cases, contrasting the decisions pre-1993 (such as Huakina ${ }^{155}$ and Tainui ${ }^{156}$ ) with the more recent judicial defeats such as the Broadcasting Assets case ${ }^{157}$ and the Maori

\author{
152 Above $n 131$. \\ 153 Above n 131, 530. \\ 154 Above n 131, 529. \\ 155 Huakina Development Trust v Waikato Valley Authority [1987] 2 NZLR 188 (HC). \\ 156 Tainui Maori Trust Board v Attorney-General [1989] 2 NZLR 513 (CA). \\ 157 New Zealand Maori Council v Attorney-General [1994] 1 NZLR 513 (PC).
}


Option case. ${ }^{158}$ A similar study of indeterminacy could be completed in relation to consultation requirements under the Resource Management Act 1991. ${ }^{159}$ Such a critique would seek to highlight that the legal discourse of the past decade is indistinguishable from political discourse. The CLS critique would further argue that the Court of Appeal's decisions have propagated a series of notions such as partnership and biculturalism which reinforce the illegitimate hierarchy of Pakeha capitalism.

A related CLS critique would attack the "myth of rights" in relation to Article Two of the Treaty of Waitangi. Such a critique would mirror the critique of civil rights in the American context: ${ }^{160}$

Rights are granted to, or bestowed upon, the powerless by the powerful. They are ultimately within the control of those with authority to interpret or rewrite the sacred texts from which they derive. To enjoy them, one must respect the forms and norms laid down by those in power. One must especially avoid excesses in behavior or demands. Rights are never "owned", merely loaned, and all too easily manipulated away or neutralised by the dismissal of their potentially transformative promise as fantasy.

According to such a critique, Treaty rights would be held to be enervating and ultimately disutile as they prevent Maori from focusing on the social transformation that is necessary to remedy the structural inequalities that have flowed from past Treaty breaches. However, it is not the purpose of this paper to fully articulate such critiques but merely to highlight the possibility of CLS concepts being applied in such a way.

The issue is whether application of CLS concepts as outlined above would be persuasive and assist in the development of a post-colonialist autochthonous critical jurisprudence. The author suggests that scholarly deconstruction of various aspects of the Treaty framework would serve as a strong foundation for critical jurisprudence in New Zealand. To date such "trashing" is absent from academic scholarship in this country. Although Kelsey argues the Court of Appeal decisions were not the victories they were claimed to be, ${ }^{161}$ she does not attempt to deconstruct the decisions or their outcomes.

158 Taiaroa v Minister of Justice [1993] 3 NZLR 421 (CA).

159 Haddon v Auckland Regional Council [1994] NZRMA 49 (PT); Ngaiwai Trust Board v Whangarei District Council [1994] NZRMA 269 (PT); Ngati Kahu v Tauranga District Council A72/94 (PT).

160 Freeman "Racism, Rights and the Quest for Equality of Opportunity: A Critical Legal Essay" (1988) 23 Harvard Civil Rights - Civil Liberties L Rev 295, 331.

161 Above n 7, 280 
However, the author submits that there are various factors that make the development of CLS scholarship in regard to the Treaty of Waitangi unlikely, even disregarding the issue of limited academic resources.

CLS is a "political location of the left" and, correspondingly, bases its conceptions of oppression and injustice on categorisations of class. However, even Kelsey, who favours a neo-marxist reconstruction of society, acknowledges the class war in New Zealand is over, the only effective resistance to Rogernomics being from Maori. ${ }^{162}$ It is submitted that the eurocentric and metropolitan assumptions of CLS are insufficient to explain the structural poverty of Maori in a settler society.

The author further submits that the primary factor militating against the utility of CLS analysis in the Treaty context is the CLS critique of rights. It is not difficult to find references to the Treaty of Waitangi being a source of rights. ${ }^{163}$ It should be noted however, that some would argue the Treaty of Waitangi is merely declarative of Maori rights. ${ }^{164}$ Any CLS based jurisprudence would apply the critique of the myth of rights to Maori claims of rights flowing from Article Two of the Treaty of Waitangi. Such a critique would paternalistically dismiss the Maori experience of seeking and obtaining rights under the Treaty as "false consciousness". As noted by McHugh, it is difficult to see Maori doing anything other than dismissing such an argument as "spurious intellectualism". ${ }^{165}$

Regardless of whether they are indeterminate, the notion of rights has enabled Maori to argue for the return of the economic base that was removed from them by the Crown last century. In a sense the focus on Treaty rights co-opts the ideology of legal liberalism. The dominant hierarchy recognises that when such rights are breached there is a moral and legal obligation on the perpetrator to compensate the rights holder. In this context the focus on the language of contract in recent Treaty discourse ${ }^{166}$ is a pragmatic use by Maori of the dominant paradigm. Accordingly, regardless of whether they are intellectually flawed, rights have an invaluable practical role in the Treaty discourse. In

162 Above n 7, 11 .

163 O'Regan "Readying the canoe on the Beach" in Ihimaera (ed) Kaupapa New Zealand: Vision Aotearoa (Bridget Williams Books, Wellington, 1994) 41, 49: "My concern has been with the basic Treaty right ...." [emphasis added].

164 Mahuta "Tainui, Kingitanga and Raupatu" in Wilson and Yeatman (eds) Justice and Identity: Antipodean Practices (Bridget Williams Books, Wellington, 1995) 18.

165 Above n 2, 102.

166 Vercoe "A Self-Sufficient Maoridom" in Ihimaera (ed) Kaupapa New Zealand: Vision Aotearoa (Bridget Williams Books, Wellington, 1994) 109, 112: "...[T]here was a contract made at Waitangi..." 
addition, as noted by CRT scholars, rights provide a source of hope and solidarity on both a collective and personal level. ${ }^{167}$

In summary, the deconstructive tools of CLS may be useful in exposing the inherent hierarchies of legal liberalism. The deconstruction of legal concepts, such as the principle of partnership developed by the Court of Appeal, would highlight the political nature of such concepts and accordingly dispel myths of neutrality and impartiality. However, the approach of CLS to the rights experience of oppressed minorities is dependent upon an assumption that structural racism is merely another form of social oppression resultant from capitalism. CLS has been informed by European and American scholars and is divorced from the perspective of colonised first nation peoples. This eurocentric and metropolitan foundation casts doubt on the utility of CLS in the further development of an autochthonous critical jurisprudence.

\section{B Critical Race Theory and the Treaty Discourse}

In contrast to CLS, the author suggests that CRT provides an opportunity to further develop our autochthonous critical jurisprudence. An initial warning should be made that CRT was developed in the context of racism towards Black Americans rather than to address the problems of first nation's peoples. Regardless of this history, it is submitted the narrative methodology of CRT could contextualise the Treaty debate by espousing the subjective experience of Maori with the law. The perspectives of Maori could inform the Treaty discourse in a manner consistent with the narrative paradigm of Maori communication. The storytelling of CRT avoids the esoteric language and "spurious intellectualism" of white male CLS academics. To a limited degree Jackson has begun this project by analysing criminal law from a Maori perspective. However, the narrative methodology is largely missing from his work.

Such narrative methodology would enable the critique of legal liberalism and all that it portrays as inevitable and natural to be communicated to those who suffer as a consequence of this structure. It is suggested that a CRT analysis of the Treaty cases could begin as follows: 168

What is the role of the word - the spoken word, the preached word, the whispered-in-the-night word, the written word, the published word - in the fight for [rangatiratanga].

As noted by McHugh, historiography has already begun this process of demystification. Redemption Songs ${ }^{169}$ is an example of a richly contextualised

167 Above n 66, 414.

168 Above n 64, 2237.

169 Above n 48. 
historiography which draws on the songs and prophecies of Te Kooti to demystify the past. It is submitted that the narrative methodology of CRT may assist the legal academy in the process of developing a jurisprudence which similarly seeks to demystify the hierarchies that are perpetuated by legal liberalism. Such a critical jurisprudence would acknowledge that the inequalities of legal liberalism are the experiential reality of many Maori (and others).

The challenge for those seeking to mould CRT into an autochthonous critical jurisprudence is to avoid the simplistic instrumentalism of Kelsey and Jackson which argues that: ${ }^{170}$

Law and the institutions of Pakeha society act in concert as instruments of oppression.

As noted by Brown in the context of racism, the transformative potential of the narrative methodology is lost if the dominant groups fail to recognise themselves in the stories told. If narratives are to be persuasively utilised in the Treaty discourse then the portrayal of Pakeha motives by radical writers must move beyond what could be labelled the colonialist model ${ }^{171}$ and replaced with an analysis that incorporates the complex and often contradictory views of Pakeha to the Treaty in the 1990s. Middle class New Zealand must recognise themselves in the stories, and not be able to dismiss the radical as referring to some red-neck that they are not. In addition, as noted by Cohen, storytelling for its own sake or as a method to provide the author with standing will only result in patronising stereotyping of Maori academics.

The following is an example of how the narrative methodology could be utilised to emphasis Maori subjective experience of the law and its institutions. ${ }^{172}$

"Not a word", Miss Dalrymple hissed.

The public gallery was packed, I knew just about all the people there. All of them stared straight ahead, down a narrow funnel of vision, as if afraid to see who was sitting left and right. That suited me fine. I hunched down, hoping I wouldn't be seen either. I felt as if I was on the wrong side.

The session that morning seemed to be one where the defendants had already leaded guilty and were being processed for sentencing.

"How do you plead?"

170 Above n 61, 32.

171 Whereby the motivations of actions such as Parihaka and laws such as the New Zealand Settlements Act 1863 are implied to Pakeha in the 1990s. The events of the New Zealand wars are used to assert the current system is merely an extension of previous colonialism.

172 Ihimaera W Bulibasha - King of the Gypsies (Penguin, Auckland, 1994) 187-188. 
"The defendant pleads guilty, Your Honour."

"Fined $£ 100$."

The judge lifted his gavel, and bang. A pair of antlers on the wall.

"How do you plead?"

"The defendant pleads guilty, Your Honour."

"Term of imprisonment, one year."

Bang, the gavel again. Another pair of antlers.

"How do you plead?"

The defendant pleads guilty, Your Honour."

This time the judge paused and looked gravely down at the defendant. "Your crime is a particularly heinous one in our society, young man. Assault on another person with intention to commit grievous harm must carry with it the maximum penalty available to the law. Five years imprisonment."

Bang. More antlers for the wall.

At each sentencing the defendant bowed his head and nodded as if all this was to be expected. His family group did the same. They were passive in the acceptance of the law and of te rori Pakeha. The Pakeha's place was to be the punisher and the Maori's place to be punished. There was a sense of implacability about the process, as if they were always right and we were always wrong.

Why didn't we fight back? We didn't know how.

The interpretation of the above story, as with CRT's narrative methodology, is dependent upon the perspective of the reader. A reader may chose to focus on the Pakeha domination of the the criminal courts, or may focus on how the story highlights the inequalities of wealth distribution in New Zealand. Ihimaera is also seeking to expand Kelsey's project of demystifying the legitimacy of the judicial process, thereby encouraging the reader to question the neutrality of the courts and the Waitangi Tribunal and their continuing role in the denial of tino rangatiratanga. It is this interpretative flexibility that enables storytelling to have transformative potential.

\section{CONCLUSION}

As noted earlier, Kelsey, McHugh, Jackson and Brookfield have each contributed significantly to development of the Treaty discourse. The jurisprudence underpinning both Kelsey's and Jackson's writing could be generically labelled as critical in that they seek to demystify the dominant ideology of legal liberalism. However, despite orthodox commentary to the contrary, Kelsey is not a CLS scholar. Her writing lacks the deconstructive methodology and the critique of rights that characterises CLS scholarship. 
Similarly, although Jackson's work has a cosmetic resemblance to CRT scholarship, the narrative methodology and pluralist epistemology is largely absent from his writing. In summary neither of the recent jurisprudential developments of CLS or CRT have permeated New Zealand jurisprudence in any meaningful way.

The author submits that, in contrast to the eurocentric and metropolitan assumptions of CLS, the subjectivity of CRT and its narrative methodology offer fertile ground for realising an autochthonous critical jurisprudence. Unlike the nihilism of CLS, CRT provides a redemptive vision of social change that accords with the optimistic nature of much of the Treaty discourse. The challenge for the legal academy is to utilise this storytelling model in way that communicates to Pakeha who do not recognise themselves in Jackson's stories of colonial oppression. If such communication can be achieved then an indigenisation of CRT could provide the transformative potential that is, in the opinion of the author, currently lacking in the critical jurisprudence of Kelsey and Jackson. However, Unger provides a cautionary note for scholars who contemplate accepting this jurisprudential challenge: ${ }^{173}$

One passes all too easily from remorseless savagery in criticism of the past to childlike innocence in the anticipation of the future. 